\title{
Collagenous colitis in children and adolescents: study of 7 cases and literature review
}

\author{
Xiuli Liu ${ }^{1}$, Shu-Yuan Xiao², Thomas P Plesec ${ }^{1}$, Wei Jiang ${ }^{3}$, John R Goldblum ${ }^{1}$ and \\ Audrey J Lazenby ${ }^{4}$ \\ ${ }^{1}$ Department of Anatomic Pathology, Cleveland Clinic, Cleveland, OH, USA; ${ }^{2}$ Department of Pathology, \\ University of Chicago, Chicago, IL, USA; ${ }^{3}$ Department of Pathology, Thomas Jefferson University Hospital, \\ Philadelphia, PA, USA and ${ }^{4}$ Department of Pathology and Microbiology, University of Nebraska Medical \\ Center, Omaha, NE, USA
}

The aim of this study is to examine the clinical and pathologic characteristics of collagenous colitis (CC) in children and adolescents. Seven patients (five females and two males, median age: 13 years, ranging from 4 to 16) were included. Four (of $7,57 \%$ ) patients presented with non-bloody watery diarrhea, one with alternating constipation and diarrhea with rectal prolapse, one with constipation, and one with normal bowel movement. Abdominal pain and weight loss were manifested in 80 and $40 \%$ patients, respectively. Two patients had celiac disease in remission. None of the patients took non-steroidal antiinflammatory agents. All patients had normal colonoscopy, but had typical histologic features of CC in colon biopsies. Four patients had clinical follow-up (24-75 months duration, median 54 months): three patients had no gastrointestinal symptoms upon follow-up, but one patient had continued symptoms of alternating diarrhea and constipation. Two patients had follow-up biopsies: one showed persistence of CC, and one had complete histologic resolution. We conclude that while $\mathrm{CC}$ is rare in children and adolescents, the clinical presentation is similar to adults, with a female preponderance, presentation with diarrhea and abdominal pain, and an association with celiac disease and other autoimmune disorders. However, compared with adults, children and adolescents are more likely to have weight loss and an atypical presentation including alternating constipation and diarrhea, constipation alone or normal bowel movements. Treatment is less standardized in children and adolescents with CC.

Modern Pathology (2013) 26, 881-887; doi:10.1038/modpathol.2012.227; published online 25 January 2013

Keywords: adolescent; budesonide; celiac disease; children; collagenous colitis; diarrhea;

intraepithelial lymphocytosis; microscopic colitis

Microscopic colitis is a clinical umbrella term for conditions characterized by a normal endoscopic appearance, but with histologic abnormalities in a patient with diarrhea. ${ }^{1}$ The most common histologic forms of microscopic colitis are collagenous colitis (CC) and lymphocytic colitis (LC), ${ }^{2-4}$ but other subtypes of colitis have also been described. ${ }^{5} \mathrm{CC}$ is generally a disease of older adults. The mean age at diagnosis is 64 years, but patient age ranges from 29 to 93 years. ${ }^{6}$ The female-to-male ratio is 3 to $1 .{ }^{6}$ The annual incidence of CC is reported in non-pediatric populations from several European and North

Correspondence: Dr X Liu, MD, PhD, Cleveland Clinic Lerner College of Medicine of Case Western Reserve University, 9500 Euclid Avenue/L25, Cleveland, OH 44195, USA.

E-mail: xiuliliu@hotmail.com

Received 18 October 2012; revised 26 November 2012; accepted 3

December 2012; published online 25 January 2013
America studies to be $0.6-5.2$ per 100000 with a prevalence of $10-39.3$ per $100000 .^{7-9}$ Patients typically seek medical attention because of chronic, watery, and non-bloody diarrhea. ${ }^{2,8}$ Associated symptoms in adult patients include abdominal pain, incontinence, urgency, flatulence, and weight loss. ${ }^{8}$ Adult patients with CC have higher rates of autoimmune thyroid disease, celiac disease, and rheumatoid arthritis. ${ }^{6}$ CC is exceedingly rare in pediatric patients, ${ }^{10}$ and therefore, data on CC of this group is scarce. In this series, we describe the clinical and pathologic features of CC patients under the age of 18 years.

\section{Materials and methods}

The pathology database at the Cleveland Clinic was searched from 1990 to 2010. Clinical records of all 
children under the age of 18 years who had a histologic diagnosis of CC were reviewed. Additional four cases were from two pathologists' files at the other participating institutions (University of Nebraska and University of Chicago). This study was approved by the Institutional Review Boards.

The inclusion criteria were (1) patients younger than 18 years of age; (2) normal colonoscopy; (3) histopathological examination of colonic biopsies showing typical features of CC, which include chronic inflammation in the lamina propria, variable intraepithelial lymphocytosis, and thickening of the subepithelial collagen plate in the absence of significant neutrophilic inflammation (defined as a predominance of neutrophils among the inflammatory cells or the presence of multifocal neutrophilic crypt abscesses) or significant crypt architecture distortion.

The clinical records of all patients who fulfilled inclusion criteria were reviewed and the following variables were documented: patient demographics, family history of any significant medical conditions including autoimmune diseases and gastrointestinal disorders, comorbid conditions/causes and risk factors, clinical symptomatology and findings on physical examination, endoscopic findings, radiological and laboratory results, histologic findings on colonic biopsies, and upper gastrointestinal tract if it was examined and biopsied, treatment and clinical course, and histologic findings in post-treatment colonic biopsies.

\section{Histologic Review of Gastrointestinal Tract Biopsies}

The biopsies from all patients were reviewed by at least two experienced gastrointestinal pathologists. Five sets of biopsies from four patients were reviewed for the following features: surface intraepithelial lymphocytes (number of intraepithelial lymphocytes in 100 surface epithelial cells in the intercryptal region), crypt intraepithelial lymphocytes (number of intraepithelial lymphocytes in 100 consecutive crypt epithelial cells), surface epithelial injury (graded as 0 (no injury), 0-1 (loss of mucin), 1 (mild injury), and 2 (severe injury with surface sloughing)), chronic inflammation in the lamina propria based on the most hypercellular area at low-power magnification $(4 \times)$ (graded as 0 (within normal range), 0-1 (minimal), 1 (chronic inflammation in the superficial portion of the lamina propria), and 2 (chronic inflammation involving the full thickness of the lamina propria)), and a thickened subepithelial collagen table (defined as any increase in subepithelial collagen). ${ }^{11,12}$ In addition, all biopsies were assessed for crypt distortion, neutrophilic inflammation, granuloma, and crypt apoptosis (recorded as the number of apoptotic bodies in 10 consecutive crypts in the area with the most brisk apoptotic activity). All available upper gastrointestinal tract biopsies were also reviewed.

\section{Results}

\section{Demographics Data and Clinical Findings}

As shown in Table 1, this cohort included five females and two males. Patient age ranged from 4 to 16 years, with a median age of 13 years.

Detailed clinical information was not available for all cases in our series either due to the retrospective nature of the study or because the case was seen as a consult. One case (case 7) has been previously reported. ${ }^{13}$ As shown in Table 1, four (of 7, 57\%) patients presented with watery non-bloody diarrhea, one $(14 \%)$ had alternating constipation and diarrhea, one $(14 \%)$ with constipation, and one $(14 \%)$ with normal bowel movements. In four patients with available clinical information, two (40\%) had weight loss. Abdominal pain was also a common symptom $(4 / 5,80 \%)$. One patient had clinical findings consistent with rectal prolapse. Three (of 3,100\%) had normal physical examination.

Two patients (of 6, 33\%) had a previous history of celiac disease, and one (of $6,17 \%$ ) had a previous history of cow's-milk intolerance. One patient (of 5, $20 \%$ ) had a family history of autoimmune disorders that included juvenile diabetes, celiac disease, and Crohn's disease. The patient presented with alternating constipation and diarrhea and rectal prolapse had a family history of diverticulosis. The remaining patients had no remarkable family history. None of the patients took non-steroidal antiinflammatory agents (NSAIDs).

\section{Endoscopic and Radiographic Findings}

Five (of 5, 100\%) patients had normal colonoscopic examination. Three (of $4,75 \%$ ) patients had normal esophagogastroduodenoscopy findings, but one patient had white plaques in the esophagus and found to have candidal esophagitis on biopsy (this patient had a recent history of budesonide oral inhalation treatment for asthma). Three patients had radiographic studies of the abdomen and/or pelvis (including computed tomography of abdomen and pelvis, ultrasound examination of gallbladder, and ultrasound examination of pelvis) all of which were normal.

\section{Histologic Findings}

All patients had typical histologic features of CC including a combination of lymphoplasmacytic infiltration of the lamina propria, surface epithelial injury, surface intraepithelial lymphocytosis, and thickening of subepithelial collagen plate (Figure 1). Two patients (of 7, 29\%) were diagnosed on biopsies taken from sigmoid-rectal and descending/sigmoid/ rectal regions. The remaining five patients (of 7 , $71 \%$ ) had multiple biopsies throughout the colon and rectum. Among these five cases, biopsies from the colon showed typical features of CC in all 5; four 
Table 1 Collagenous colitis in children and adolescents in this series and literature cases

\begin{tabular}{|c|c|c|c|c|c|c|c|c|c|}
\hline \multirow[t]{2}{*}{$\begin{array}{l}\text { Case \# or } \\
\text { reference }\end{array}$} & \multirow[t]{2}{*}{$\begin{array}{l}\text { Sex/age } \\
\text { (years) }\end{array}$} & \multicolumn{2}{|r|}{ Symptoms } & \multirow[t]{2}{*}{ Colonoscopy } & \multirow[t]{2}{*}{ Family history } & \multirow[t]{2}{*}{ Concomitant disease } & \multirow[t]{2}{*}{ Treatment } & \multirow[t]{2}{*}{ Follow-up } & \\
\hline & & Diarrhea & Others & & & & & & \\
\hline Case 1 & $\mathrm{~F} / 16$ & None & $\begin{array}{l}\text { Weight loss, abdominal } \\
\text { pain, nausea }\end{array}$ & Normal & None & GERDa & $\begin{array}{l}\text { Esomeprazole, Ondansetron, } \\
\text { Bisacodyl }\end{array}$ & $\begin{array}{l}\text { Well at } 36 \text { months without } \\
\text { gastrointestinal symptoms }\end{array}$ & \\
\hline Case 2 & $\mathrm{~F} / 13$ & None & $\begin{array}{l}\text { Constipation, weight loss, } \\
\text { and abdominal pain }\end{array}$ & Normal & None & GERD, asthma & Milralax & $\begin{array}{l}\text { Well at } 72 \text { months without } \\
\text { gastrointestinal symptoms }\end{array}$ & \\
\hline Case 3 & $\mathrm{M} / 13$ & $\begin{array}{l}\text { Alternating } \\
\text { diarrhea and } \\
\text { constipation, } \\
\text { worsening of } \\
\text { diarrhea prior to } \\
\text { presentation }\end{array}$ & Mild abdominal pain & Normal & Diverticulosis & Rectal prolapse & $\begin{array}{l}\text { Cholestyramine and Asacol (for } \\
\text { first episode); Entocort and } \\
\text { Culturelle (for the second episode); } \\
\text { followed by Pepto-Bismol }\end{array}$ & $\begin{array}{l}\text { Intermittent course with } \\
\text { diarrhea } 2-3 / \text { day and rectal } \\
\text { prolapse at } 75 \text { months }\end{array}$ & \\
\hline Case 4 & $\mathrm{~F} / 14$ & Diarrhea & Abdominal pain & Normal & $\mathrm{N} / \mathrm{A}$ & $\begin{array}{l}\text { Celiac disease in remission on } \\
\text { GFD }^{\mathrm{b}}\end{array}$ & None & N/A & \\
\hline Case 5 & $\mathrm{M} / 4$ & $\begin{array}{l}\text { Explosive } \\
\text { diarrhea }\end{array}$ & $\mathrm{N} / \mathrm{A}^{\mathrm{c}}$ & N/A & $\mathrm{N} / \mathrm{A}$ & N/A & N/A & N/A & \\
\hline Case 6 & $\mathrm{~F} / 10$ & $\begin{array}{l}\text { Explosive } \\
\text { diarrhea }\end{array}$ & N/A & N/A & $\begin{array}{l}\text { Celiac disease, } \\
\text { Crohn's disease, } \\
\text { juvenile diabetes }\end{array}$ & $\begin{array}{l}\text { Prior history of celiac disease. } \\
\text { When seen, normal tTGd; } \\
\text { duodenal biopsy close to normal } \\
\text { with slight increase IEL } \mathrm{IE}^{\mathrm{e}}\end{array}$ & N/A & N/A & \\
\hline Case 7 & $\mathrm{~F} / 4^{\mathrm{f}}$ & $\begin{array}{l}\text { Chronic watery } \\
\text { diarrhea }\end{array}$ & No & Normal & None & $\begin{array}{l}\text { Prior history of cow's-milk protein } \\
\text { intolerance }\end{array}$ & Entocort & $\begin{array}{l}\text { Well at } 24 \text { months with } \\
\text { normal colonic mucosa biopsy }\end{array}$ & \\
\hline $\begin{array}{l}\text { Essenlinckx W } \\
\text { et al }{ }^{19}\end{array}$ & $\mathrm{~F} / 15$ & $\begin{array}{l}\text { Abundant and } \\
\text { urgent watery } \\
\text { diarrhea }\end{array}$ & & Normal & Not available & Juvenile scleroderma & $\begin{array}{l}\text { First episode diarrhea appeared to } \\
\text { respond to sulfasalazine }\end{array}$ & $\begin{array}{l}\text { Intermittent and progressive } \\
\text { clinical course }\end{array}$ & \\
\hline $\begin{array}{l}\text { Camarero } \mathrm{C} \\
\text { et } a 2^{20}\end{array}$ & $\mathrm{~F} / 15$ & Watery diarrhea & & Normal & $\begin{array}{l}\text { No family history of } \\
\text { autoimmunity or } \\
\text { immunodeficiency }\end{array}$ & $\begin{array}{l}\text { Congenital hypothyroidism, type I } \\
\text { diabetes mellitus, Collagenous } \\
\text { gastritis, Aeromonas hydrophila } \\
\text { gastrointestinal infection }\end{array}$ & No response to loperamide & & \\
\hline $\begin{array}{l}\text { Camarero C } \\
\text { et } a 2^{20}\end{array}$ & $\mathrm{~F} / 2$ & Watery diarrhea & & Normal & Not available & $\begin{array}{l}\text { Congenital cardiac defect, } \\
\text { Aeromonas hydrophila } \\
\text { gastrointestinal infection }\end{array}$ & $\begin{array}{l}\text { Colloidal bismuth subcitrate } \\
\text { resolved diarrhea }\end{array}$ & $\begin{array}{l}\text { Intermittent diarrhea and } \\
\text { follow-up biopsies showed } \\
\text { less prominent lymphocytosis } \\
\text { but typical features of } \\
\text { collagenous colitis }\end{array}$ & 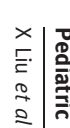 \\
\hline $\begin{array}{l}\text { Benchimol E } \\
\text { et } a^{21}\end{array}$ & $\mathrm{~F} / 4$ & $\begin{array}{l}\text { Chronic watery } \\
\text { diarrhea }\end{array}$ & & Mildly edematous and friable & Not available & Eosinophilic gastritis & $\begin{array}{l}\text { Initially diagnosed as lymphocytic } \\
\text { colitis and gastritis not responding } \\
\text { to sulfasalazine and disease } \\
\text { progressed to collagenous colitis. } \\
\text { Diarrhea responded to ketotifen }\end{array}$ & & \\
\hline $\begin{array}{l}\text { Vanderhoof JA } \\
\text { et } a l^{13}\end{array}$ & $\mathrm{~F} / 4$ & Same as case 7 & Same as case 7 & Same as case 7 & Same as case 7 & Same as case 7 & Same as case 7 & Same as case 7 & \\
\hline $\begin{array}{l}\text { O'Beirne JP, } \\
\text { Ireland } A^{22}\end{array}$ & $\mathrm{~F} / 16$ & $\begin{array}{l}\text { Chronic watery } \\
\text { diarrhea }\end{array}$ & & Normal & Not available & None & $\begin{array}{l}\text { No response to mesalazine, } \\
\text { bismuth subsalicylate, and } \\
\text { sulfasalazine. Responded to } \\
\text { prednisolone }\end{array}$ & $\begin{array}{l}\text { Became steroid dependent } \\
\text { and progressed to Crohn's } \\
\text { disease } 10 \text { years after the } \\
\text { initial diagnosis of } \\
\text { collagenous colitis }\end{array}$ & $\overline{\bar{n}}$ \\
\hline $\begin{array}{l}\text { Billiemaz K } \\
\text { et a } \text { I }^{33}\end{array}$ & M/9 months & Watery diarrhea & Low weight for height & $\begin{array}{l}\text { Diffusely pale, thickened, and } \\
\text { nodular, with disappearance } \\
\text { of the normal vascular pattern }\end{array}$ & Not available & $\begin{array}{l}\text { Collagenous gastritis and } \\
\text { collagenous sprue }\end{array}$ & $\begin{array}{l}\text { Clinicopathologic disease } \\
\text { progression despite aggressive } \\
\text { treatment including prednisolone } \\
\text { alternating with budesonide, } \\
\text { parenteral nutrition, and GFD }\end{array}$ & $\begin{array}{l}\text { Clinicopathologic disease } \\
\text { progression }\end{array}$ & \\
\hline $\begin{array}{l}\text { Suskind D } \\
\text { et } a 2^{24}\end{array}$ & $\mathrm{M} / 15$ & $\begin{array}{l}\text { Loose, non- } \\
\text { bloody stool }\end{array}$ & $\begin{array}{l}\text { Abdominal pain and } \\
\text { weight loss }\end{array}$ & Normal & Not available & $\begin{array}{l}\text { Autoimmune hemolytic anemia, } \\
\text { collagenous gastritis, and } \\
\text { collagenous sprue }\end{array}$ & Responded to prednisone & $\begin{array}{l}\text { Relapsed after prednisone } \\
\text { cessation. Responded to } \\
\text { lansoprazole and mesalamine }\end{array}$ & \\
\hline \multicolumn{10}{|c|}{$\begin{array}{l}{ }^{a} \text { GERD: gastroesophageal reflux disease. } \\
\mathrm{b}_{\text {GFD: gluten-free diet. }} \\
{ }_{\mathrm{C}} \mathrm{N} / \mathrm{A} \text { : information not available. } \\
\mathrm{d}_{\text {tTG: antitissue transglutaminase antibody. }} \\
{ }_{\text {IEL: surface intraepithelial lymphocyte. }} \\
{ }^{\mathrm{f}} \text { This is the same case as reported by Vanderhoof et al. }{ }^{13}\end{array}$} \\
\hline
\end{tabular}



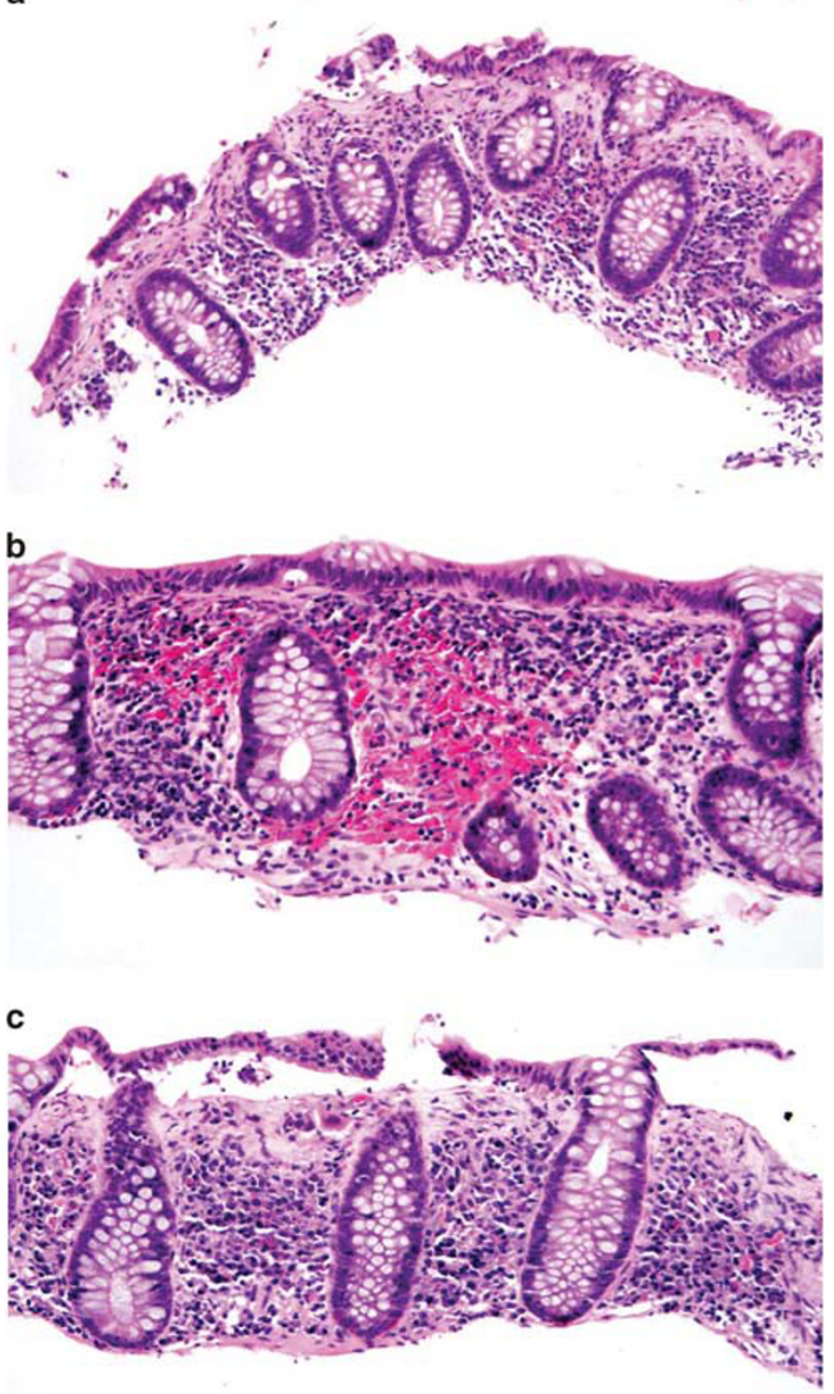

Figure 1 Histologic features of collagenous colitis. (a) Surface epithelial injury and intraepithelial lymphocytosis, thickening of subepithelial collagen table $(\mathrm{H} \& \mathrm{E}$ stain, $100 \times)$. (b) Increased lamina propria inflammation and intraepithelial lymphocytosis (H\&E stain, $200 \times)$. (c) Focal sloughing of surface epithelium and thickening of subepithelial collagen table (H\&E stain, $200 \times$ ).

patients also had rectal biopsies at their initial presentation and two had CC on rectal biopsy, but one of the four had a rectal biopsy with only increased intraepithelial lymphocytes but no increase in collagen and one had a normal rectal biopsy.

The histologic findings of pediatric CC in colorectal biopsies are shown in Table 2. The mean number of surface intraepithelial lymphocytes was 37 per 100 epithelial cells (s.d. 24). Overall, 23 (of $25,92 \%$ ) biopsies had surface intraepithelial lymphocytosis (defined as > 20 intraepithelial lymphocytes per 100 surface epithelial cells). The mean number of crypt intraepithelial lymphocytes was 10 per 100 crypt epithelial cells (s.d. 7). In addition,
22 (of 26, 85\%) biopsies had increased chronic inflammation in the lamina propria and 25 (of 26, $96 \%$ ) biopsies had surface epithelial injury ranging from mild-to-severe injury including surface denudation. A thickened subepithelial collagen plate with a 'dripping' appearance was noted in 24 (of 26, $92 \%$ ) biopsies from 4 (of $4,100 \%$ ) patients, with the absence of the increased collagen in the rectal biopsies in two patients (but these two had increased collagen in more proximal biopsies). Focal crypt distortion was noted in two biopsies (8\%) from two patients (of 4, 50\%). Focal neutrophilic inflammation (either involving crypts or lamina propria) was noted in two biopsies (of 26, $8 \%$ ) from two patients (of $4,50 \%$ ).

One patient (case 3) had two biopsies performed 1 year apart. The second set of biopsies had more severe surface epithelial injury, chronic inflammation, and a thicker subepithelial collagen plate. Of note, the second set of biopsies showed a higher number of apoptotic bodies in crypts (3.2 (s.d. 1.7)/ 10 consecutive glands vs 0.67 (s.d. 0.5 ) in the first set of biopsies). In the remaining three cases, only rare apoptotic bodies were identified in crypts (Table 2).

Five patients had biopsies from the upper gastrointestinal tract including four biopsies from the duodenum, four from the stomach, and three from the esophagus. Among them, one had intraepithelial lymphocytosis in the duodenal mucosa (defined as $>25$ intraepithelial lymphocytes/100 epithelial cells). ${ }^{14}$ Three had (of $4,75 \%$ ) chronic gastritis including two with lymphocytic gastritis and one had candidal esophagitis (patient was on budesonide). One of the three patients who had biopsies from the terminal ileum had intraepithelial lymphocytosis (defined as $\geq 10$ intraepithelial lymphocytes/100 surface epithelial cells ${ }^{15}$ but preserved villous architecture.

\section{Treatment and Follow-Up}

For the five patients with treatment information available, two (cases 3 and 7) were treated with budesonide (Entocort), one after initial failure of mesalamine (Asacol) and cholestyramine and histologic progression of disease. This patient had continued mild diarrhea (2-3 stools/per day) alternating with constipation but no additional biopsy was performed. The other patient had clinical resolution and histologic normalization of the colonic mucosa (case 7). One patient had spontaneous resolution of diarrhea without treatment (case 4). The remaining patients were treated with symptom-relieving agents including ondansetron and bisacodyl (case 1, presented with weight loss and abdominal pain but lacked diarrhea), and polyethylene glycol 3350 (Miralax) (case 2, presented with constipation) and all of them had their symptoms relieved with the above treatments. 
Table 2 Histologic findings of collagenous colitis in children and adolescents

\begin{tabular}{|c|c|c|c|c|c|c|c|}
\hline Biopsy & Location & $\begin{array}{c}\text { Number of } \\
\text { surface IEL } L^{a}, b\end{array}$ & $\begin{array}{l}\text { Number of } \\
\text { crypt IEL }\end{array}$ & $\begin{array}{c}L P^{d} \\
\text { inflammation }\end{array}$ & $\begin{array}{l}\text { Surface } \\
\text { injurye }\end{array}$ & $\begin{array}{c}\text { Collagen } \\
\text { table } \\
\text { thickening }\end{array}$ & $\begin{array}{c}\text { Crypt } \\
\text { apoptosis }^{\circ}\end{array}$ \\
\hline \multirow[t]{6}{*}{ Case 1} & Cecum & 40 & 16 & 2 & 1 & 1 & 0 \\
\hline & Ascending & 35 & 8 & 2 & 1 & 1 & 0 \\
\hline & Transverse & 34 & 6 & 2 & 1 & 1 & 0 \\
\hline & Descending & 17 & 3 & 1 & 1 & 1 & 0 \\
\hline & Sigmoid & 17 & 5 & 0 & $0-1$ & 1 & 0 \\
\hline & Rectum & 10 & 5 & 0 & 0 & 0 & 0 \\
\hline \multirow[t]{6}{*}{ Case 2} & Cecum & 11 & 6 & 2 & 1 & 1 & 1 \\
\hline & Right & 23 & 11 & 1 & 1 & 1 & 1 \\
\hline & Transverse & 27 & 11 & 1 & 1 & 1 & 1 \\
\hline & Descending & 44 & 7 & 1 & 2 & 1 & 1 \\
\hline & Sigmoid & 27 & 7 & 1 & 1 & 1 & 1 \\
\hline & Rectum & 18 & 6 & $0-1$ & $0-1$ & 1 & 1 \\
\hline \multirow[t]{6}{*}{ Case 3-1 } & Cecum & 70 & 9 & 0 & $0-1$ & 1 & 0 \\
\hline & Ascending & 70 & 15 & 1 & $0-1$ & 1 & 1 \\
\hline & Transverse & 61 & 12 & 1 & 1 & 1 & 1 \\
\hline & Descending & 60 & 8 & 1 & 1 & 1 & 1 \\
\hline & Sigmoid & 72 & 15 & 1 & 1 & 1 & 1 \\
\hline & Rectum & 40 & 15 & 0 & $0-1$ & 1 & 0 \\
\hline \multirow[t]{6}{*}{ Case 3-2 } & Cecum & 47 & 15 & 1 & 1 & 0 & 1 \\
\hline & Ascending & 42 & 6 & 1 & 1 & 1 & 5 \\
\hline & Transverse & 48 & 10 & 1 & 1 & 1 & 5 \\
\hline & Descending & 79 & 12 & 1 & 1 & 1 & 2 \\
\hline & Sigmoid & $\mathrm{N} / \mathrm{A}^{\mathrm{h}}$ & 10 & 1 & 1 & 1 & 4 \\
\hline & Rectum & 100 & 26 & 1 & 1 & 1 & 2 \\
\hline \multirow[t]{2}{*}{ Case 4} & $\begin{array}{l}35 \mathrm{~cm} \text { (Descending- } \\
\text { sigmoid) }\end{array}$ & 71 & 25 & 1 & 1 & 1 & 2 \\
\hline & $15 \mathrm{~cm}$ (Recto-sigmoid) & 70 & 31 & $0-1$ & 1 & 1 & 0 \\
\hline
\end{tabular}

a IEL: intraepithelial lymphocyte.

${ }^{\text {b }}$ Surface IEL recorded as number of IELs per 100 surface epithelial cells.

${ }^{\mathrm{C}}$ Crypt IEL recorded as number of IELs per 100 crypt epithelial cells.

d LP: lamina propria inflammation evaluated as: $0=$ normal, $0-1=$ minimal, $1=$ chronic inflammation in the upper $1 / 2$ LP, $2=$ chronic inflammation in the entire LP.

esurface injury evaluated as: $0=$ no injury, $0-1=$ loss of mucin, $1=$ mild injury, $2=$ severe injury with sloughing.

${ }^{\mathrm{f}}$ Collagen table thickening assessed as: $0=$ absent, $1=$ present.

gCrypt apoptosis evaluated as number of apoptotic bodies per 10 consecutive crypts.

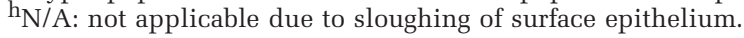

Of the four patients with follow-up data (cases 1-3 and 7, 24-75 months duration, median 54 months), three patients had no further gastrointestinal symptoms and one had a relapsing clinical course with recurrent abdominal pain, alternating diarrhea and constipation, and rectal prolapse (case 3). None of the patients developed Crohn's disease or ulcerative colitis during the follow-up period.

\section{Discussion}

CC is a well-recognized form of chronic colitis in adults. It had only been rarely reported in children and adolescents and some of the cases may not be bona fide cases as commented previously. ${ }^{16}$ In some earlier reports, the photomicrographs did not show all the microscopic features of CC in colonic $^{17}$ or rectal biopsies, ${ }^{18}$ and some only showed a thickened basement membrane without significant epithelial injury or increased inflammation. ${ }^{10,17}$ More recent cases in the pediatric literature do appear to be genuine CC, but these are single case reports.
To our knowledge, this report is the only series of CC cases in children and adolescents that highlights similarities as well as differences from the adult population. The pediatric CC cases from the literature ${ }^{13,19-24}$ and from our series (Table 1) had a female-to-male ratio of 2.5 (10:4) and most of them presented with diarrhea $(11 / 14,79 \%)$ (Table 1), similar to the adult population. In our series, the most common symptoms were abdominal pain $(4 / 5$, $80 \%$; Table 1). These findings are similar to CC in adults, in which diarrhea-associated symptoms include abdominal pain (73\%). ${ }^{8}$ While weight loss has been reported in $29-49 \%$ of adult cases, ${ }^{8,25}$ it is not a common complaint in previously reported pediatric cases (see Table 1, cases prior to our series), although our series had two patients with significant weight loss, either alone, or accompanied by diarrhea or constipation.

Unlike adults, children more often have an atypical presentations including constipation or alternating constipation and diarrhea, which had not been reported previously in this patient population (see Table 1, cases prior to our series). Of note, the patient with alternating constipation and 
diarrhea had concomitant severe rectal prolapse. Extensive workup failed to identify an etiology for rectal prolapse other than CC in this case. However, it remains to be determined if CC is truly the cause of rectal prolapse in this case.

A small percentage of adult patients with CC have autoimmune disorders including autoimmune thyroid disease, celiac disease, and rheumatoid arthritis. ${ }^{6}$ This association seems to be more common in children, as 5/14 (36\%) children had autoimmune diseases diagnosed prior to or simultaneously with the diagnosis of CC, including celiac disease (2), collagenous sprue and gastritis (2), and juvenile scleroderma (1). Celiac disease was noted in $29 \%$ (4/14) pediatric cases (Table 1$)$, higher than that seen in adult population (5/171). ${ }^{6}$ Further, in pediatric population, celiac disease was more often diagnosed prior to or at the same time as CC (4/4 (100\%)), compared with $20 \%(1 / 5)$ celiac disease diagnosed prior to CC in the adult population. ${ }^{6}$ In pediatric patients with celiac disease and CC, the latter did not always coincide with active celiac disease, as $50 \%(2 / 4)$ of patients developed CC when their celiac disease was in remission on a gluten-free diet. Our results suggest that serology and histologic evidence of remission of celiac disease should not exclude the possibility of CC as a cause of watery diarrhea in these patients.

Five patients (of 7, 71\%) in our series had multiple biopsies separately submitted at their initial presentation. While the biopsies from the colon showed typical features of CC, two rectal biopsies (50\%) from four patients at their initial presentation were either normal or only showed intraepithelial lymphocytosis without thickened collagen band. Absolute and relative rectal sparing in pediatric CC seen in our series may explain the relatively normal rectal mucosa in previously reported cases of 'pediatric CC,' which had typical clinical presentations. ${ }^{18}$ Thus, a normal rectal biopsy does not exclude the possibility of CC in children. As in adults, if CC is a consideration, biopsies should include areas proximal to the rectosigmoid.

Histologic abnormalities have been noted in the upper gastrointestinal tract in children and adolescents with CC. Two cases had collagenous gastritis, two lymphocytic gastritis (our series), and one nonspecific chronic gastritis (our series). Two of three patients with collagenous gastritis in the literature also had collagenous sprue (Table 1). The patients with lymphocytic gastritis or non-specific chronic gastritis in our series did not have celiac disease. Also, one of four duodenal biopsies available for histologic review had intraepithelial lymphocytosis but no clinical evidence of celiac disease. One of three terminal ileal biopsies available for histologic review had intraepithelial lymphocytosis but no clinical evidence of celiac disease. These findings are consistent with the previously reported intraepithelial lymphocytosis in terminal ileum in adult patients with CC. ${ }^{26,27}$
While clinical trials have shown the efficacy of budesonide treatment in adult patients with CC, ${ }^{28-32}$ treatment for children appears to be largely empiric with various agents (Table 1). Overall, sulfasalazine, mesalazine, and cholestyramine were either ineffective or only partially effective. Four of five patients treated with corticosteroids appeared to respond, at least temporarily, but two had relapse after cessation of corticosteroids and one became steroid-dependent $(1 / 5,20 \%)$, similar to what has been observed in adult patients. One case had a progressive clinical course in spite of aggressive treatment including corticosteroids.

One child with CC has been reported to progress to Crohn's disease 10 years after the initial diagnosis of CC. ${ }^{22}$ However, in our series of four cases with a median follow-up period of 54 months (range: 24-75), none progressed to Crohn's disease.

The etiology of pediatric CC is as elusive as in adult patients, but appears to be associated with underlying immune abnormalities, common variable immunodeficiency, ${ }^{33}$ celiac disease, and aeromonas hydrophila infection in some cases, and to be a component of collagenous gastroenterocolitis (Table 1). Unlike adult patients, medications, particularly NSAIDs, ${ }^{34}$ do not seem to play a significant role in the development of pediatric CC.

In summary, CC occurs rarely in children. Similar to adults, childhood CC has a female predilection and most present with diarrhea and abdominal pain, but atypical presentations (weight loss and constipation) can also be seen. In addition, associated autoimmune disorders including celiac disease, lymphocytic gastritis, and collagenous gastritis are seen at a higher rate in these patients. No association with NSAID usage was found in pediatric cases. While therapy for adult CC is fairly standardized, the treatments for children vary; but most pediatric patients respond, at least temporarily, to corticosteroid therapy.

\section{Disclosure/conflict of interest}

The authors declare no conflict of interest.

\section{References}

1 Read NW, Krejs GJ, Read MG, et al. Chronic diarrhea of unknown origin. Gastroenterology 1980;78: 264-271.

2 Lindstrom CG. 'Collagenous colitis' with watery diarrhea-a new entity? Pathol Eur 1976;11:87-89.

3 Lazenby AJ, Yardley JH, Giardiello FM, et al. Lymphocytic ('microscopic') colitis: a comparative histopathologic study with particular reference to collagenous colitis. Hum Pathol 1989;20:18-28.

4 Giardiello FM, Lazenby AJ, Bayless TM, et al. Lymphocytic (microscopic) colitis: clinicopathologic study of 18 patients and comparison to collagenous colitis. Dig Dis Sci 1989;34:1730-1738. 
5 Levison DA, Lazenby AJ, Yardley JH. Microscopic colitis cases revisited. Gastroenterology 1993;105: 1594-1596.

6 Olesen M, Eriksson S, Bohr J, et al. Microscopic colitis: a common diarrhoeal disease. An epidemiological study in Örebro, Sweden, 1993-1998. Gut 2004;53:346-350.

7 Fernández-Bańares F, Salas A, Forné $\mathrm{M}$, et al. Incidence of collagenous and lymphocytic colitis: a 5-year population-based study. Am J Gastroenterol 1999;94:418-423.

8 Kao KT, Pedraza B, McClune A, et al. Microscopic colitis: a large retrospective analysis from a health maintenance organization experience. World J Gastroenterol 2009;15:3122-3127.

9 Pardi DS, Loftus EV, Smyrk TC, et al. The epidemiology of microscopic colitis: a population based study in Olmsted County, Minnesota. Gut 2007;56: 504-508.

10 Gremse DA, Boudreaux CW, Manci EA. Collagenous colitis in children. Gastroenterology 1993;104:906-909.

11 Lazenby AJ. Collagenous and lymphocytic colitis. Semin Diagn Pathol 2005;22:295-300.

12 Lazenby AJ, Yardley JH, Giardiello FM, et al. Pitfalls in the diagnosis of collagenous colitis: experience with 75 cases from a registry of collagenous colitis at the Johns Hopkins Hospital. Hum Pathol 1990;21:905-910.

13 Vanderhoof JA, Goble K, Young RJ. Collagenous colitis in a 4-year-old child: response to budesonide. J Pediatr Gastroenterol Nutr 2010;50:688-690.

14 Hayat M, Cairns A, Dixon MF, et al. Quantitation of intraepithelial lymphocytes in human duodenum: what is normal? J Clin Pathol 2002;55:393-394.

15 Liu L, Talmon G. Quantification of intraepithelial lymphocytes in normal pediatric small intestinal allograft and native ilea. Transplant Proc 2011;43:1831-1835.

16 Yardley JH, Lazenby AJ, Kornacki S. Collagenous colitis in children. Gastroenterology 1993;105:647-648.

17 Perisic VN, Kokai G. Diarrhoea caused by collagenous colitis. Arch Dis Child 1989;64:867-869.

18 Busuttil A. Collagenous colitis in a child. Am J Dis Child 1989;143:998-1000.

19 Esselinckx W, Brenard R, Colin JF, et al. Juvenile scleroderma and collagenous colitis. The first case J Rheumatol 1989;16:834-836.

20 Camarero C, Leon F, Colino E, et al. Collagenous colitis in children: clinicopathologic, microbiologic, and immunologic features. J Pediatr Gastroenterol Nutr 2003;37:508-513.

21 Benchimo E, Kirsch R, Viero S, et al. Collagenous colitis and eosinophilic gastritis in a 4-year old girl: a case report and review of the literature. Acta Paediatr 2007;96:1365-1367.

22 O'Beirne JP, Ireland A. Progression of collagenous colitis to Crohn's disease. Eur J Gastroenterol Hepatol 2005;17:573-575.

23 Billiémaz K, Roble-Medranda C, Le Gall C, et al. A first report of collagenous gastritis, sprue, and colitis in a 9-month-old infant: 14 years of clinical, endoscopic, and histologic follow-up. Endoscopy 2009;41 (Suppl 2):E233-E234.

24 Suskind D, Wahbeh G, Murray K, et al. Collagenous gastritis, a new spectrum of disease in pediatric patients: two case reports. Cases J 2009;2:7511.

25 Jobse P, Flens MJ, Loffeld RJLF. Collagenous colitis: description of a single centre series of 83 patients. EurJ Intern Med 2009;20:499-502.

26 Sapp H, Ithamukkala S, Brien TP, et al. The terminal ileum is affected in patients with lymphocytic or collagenous colitis. Am J Surg Pathol 2002;26:1484-1492.

27 Padmanabhan V, Callas PW, Li SC, et al. Histopathological features of the terminal ileum in lymphocytic and collagenous colitis: a study of 32 cases and review of literature. Mod Pathol 2003;16:115-119.

28 Baert F, Schmit A, D'Haens G, et al. Budesonide in collagenous colitis: a double-blind placebo-controlled trial with histologic follow-up. Gastroenterology 2002;122:20-25.

29 Bonderop OK, Hansen JB, Birket-Smith L, et al. Budesonide treatment of collagenous colitis: a randomized, double blind, placebo controlled trial with morphometric analysis. Gut 2003;52:248-251.

30 Miehlke S, Heymer P, Bethke B, et al. Budesonide treatment for collagenous colitis: a randomized, double-blinded, placebo-controlled, multicenter trial. Gastroenterology 2002;123:978-984.

31 Miehlke S, Madisch A, Bethke B, et al. Oral budesonide for maintenance treatment of collagenous colitis: a randomized, double-blind, placebo-controlled trial. Gastroenterology 2008;135:1510-1516.

32 Bonderop OK, Hansen JB, Teglbjaerg PS, et al. Longterm budesonide treatment of collagenous colitis: a randomized, double-blind, placebo-controlled trial. Gut 2009;58:68-72.

33 Daniels JA, Lederman HM, Maitra A, et al. Gastrointestinal tract pathology in patients with common variable immunodeficiency (CVID): a clinicopathologic study and review. Am J Surg Pathol 2007;31:1800-1812.

34 Giardiello FM, Hansen FC, Lazenby AJ, et al. Collagenous colitis in setting of nonsteroidal anti-inflammatory drugs and antibiotics. Dig Dis Sci 1990;35:257-260. 